\title{
Distribusi Keganasan Organ Tiroid Berdasarkan Pemeriksaan Histopatologi di Kota Pekanbaru
}

\author{
Wiwit Ade Fidiawaty ${ }^{1}$, Selvialiany ${ }^{2 *}$, Welly Zulfikar ${ }^{3}$
}

\begin{abstract}
Cancer is one of the leading causes of death. Cancer can occur in various organs of the human body. Thyroid cancer is one of the most common cancer. Pathological based registration indicates that thyroid cancer is the ninth of the overall cancer and the most common type of endocrine related cancer. The purpose of this research was to determine the distribution of thyroid cancer in Pekanbaru's Hospital during 2009-2013 based on histopathologic type, age and gender. This research was a retrospective study were retrieved based on result of hospital's histopathology laboratories and histopathology laboratories centers in Pekanbaru. The results showed 163 cases of thyroid cancer. Mostly found at RSUD Arifin Achmad Riau Province as many as 106 cases (65\%). The cancer was dominated by women (83,4\%). The age range of most thyroid cancer is 35-44 years $(24,5 \%)$. The most common histopathological type of thyroid cancer was papillary thyroid cancer, as many as 111 cases $(68,1 \%)$.
\end{abstract}

Keywords: thyroid cancer, distribution, histopathology type

Kanker merupakan salah satu penyebab utama kematian di seluruh dunia dan menyumbang 7,6 juta kematian (13\% dari semua kematian) pada tahun 2008 dan angka ini terus meningkat setiap tahunnya. Tahun 2012, kanker menyumbang 8,2 juta kematian (60\% dari semua kasus baru di Afrika, Asia, Amerika Selatan, dan Amerika Tengah). ${ }^{1}$ Menurut Badan Registrasi Kanker Indonesia yang melakukan pengumpulan data dari 15 kota di Indonesia, jumlah kasus kanker pada tahun 2011 berjumlah 24.844 kasus. $^{2}$

Salah satu kanker yang cukup banyak ditemukan kasusnya adalah kanker tiroid. Berdasarkan dari "Pathological based registration" di Indonesia, insiden kanker tiroid menempati urutan ke sembilan dari keseluruhan kanker dan merupakan keganasan terbanyak dari sistem endokrin. ${ }^{3}$ Tiroid menempati urutan keenam dari sepuluh tumor tersering menurut tumor primer dari seluruh senter

\footnotetext{
1 Bagian Patologi Anatomi FK Universitas Riau

2 Penulis untuk korespondensi : FK Universitas Riau. Jalan Diponegoro No. 1, Pekanbaru.

* Korespondensi penulis : selvia.liany@yahoo.com

3 Bagian Bedah FK Universitas Riau
}

di Indonesia tahun 2011. ${ }^{2}$ Kanker tiroid itu sendiri merupakan kanker yang terbentuk di kelenjar tiroid (yaitu organ yang berada di dasar tenggorokan yang berfungsi membantu mengontrol detak jantung, tekanan darah, suhu tubuh, dan berat badan). ${ }^{4}$

Jumlah kasus baru kanker tiroid di dunia adalah 13,5:100.000 per tahun. Jumlah kematiannya adalah 0,5:100.000 per tahun. Angka ini disesuaikan menurut umur dan berdasarkan data kasus dan data kematian dari 2008-2012. Tahun 2011, diketahui 566.708 orang yang didiagnosis kanker tiroid di Amerika Serikat, dan mengalami peningkatan pada tahun 2012 menjadi 601.789 orang. ${ }^{4}$ Di Indonesia, menurut pendataan instalasi deteksi dini dan promosi kesehatan RS Kanker Dharmais 2010-2013, kasus baru kanker tiroid meningkat setiap tahunnya. ${ }^{5}$

Kanker tiroid sebagian besar terjadi pada orang dewasa, namun pada beberapa kasus, terutama karsinoma papiler, dapat timbul pada masa kanakanak. Ditemukan juga adanya dominasi perempuan pada pasien yang berusia dewasa muda dan pertengahan. Hal ini diketahui berkaitan dengan ekspresi reseptor estrogen di epitel tiroid neoplastik. Kasus yang timbul pada masa anak atau dewasa lanjut terdistribusi merata pada laki-laki dan perempuan. ${ }^{6}$ 
Pemeriksaan jaringan pembedahan atau histopatologi merupakan gold standard diagnosis karsinoma tiroid pasca bedah. Biopsi pada karsinoma tiroid yang operable tidak dibenarkan. Biopsi hanya dilakukan pada karsinoma tiroid yang in-operable, seperti pada karsinoma anaplasik. ${ }^{3}$ Pada diagnosis pra-operasi, pemeriksaan yang sering dilakukan adalah pemeriksaan sitologi aspirasi jarum halus/Fine needle aspiration cytology (FNAC). ${ }^{7}$ Hasil pemeriksaan tersebut akan didapatkan tipe-tipe dari karsinoma tiroid yang antara lain karsinoma papiler, yang merupakan tipe karsinoma tiroid yang paling sering terjadi yaitu 75$85 \%$ dari keseluruhan kasus karsinoma tiroid, karsinoma folikuler sebanyak 10-20\%, karsinoma medular 5\%, dan karsinoma anaplastik, yang merupakan tipe karsinoma tiroid yang paling jarang ditemui dengan kurang dari 5\% dari keseluruhan kasus. ${ }^{6}$

Tujuan penelitian ini adalah untuk mengetahui insiden keganasan organ tiroid berdasarkan pemeriksaan histopatologi serta proporsi kasus pada masing-masing rumah sakit di Kota Pekanbaru, distribusi keganasan organ tiroid menurut jenis kelamin, distribusi keganasan organ tiroid menurut usia, dan distribusi kegansan tiroid menurut tipe histopatologis.

\section{METODE}

Penelitian ini merupakan penelitian deskriptif dengan jenis cross sectional retrospektif. Populasi penelitian adalah seluruh medical record yang memiliki catatan pemeriksaan kasus keganasan primer organ tiroid berdasarkan pemeriksaan histopatologi pada rekam medis rumah sakit di Kota Pekanbaru serta laboratorium sentra patologi anatomi tahun 2009-2013. Sampel meliputi seluruh populasi (total sampling) dari penderita keganasan primer organ tiroid berdasarkan pemeriksaan histopatologi pada rumah sakit di Kota Pekanbaru tahun 2009-2013 dengan variabel jenis kelamin, usia, dan tipe histopatologi.

\section{HASIL}

Penelitian ini dilakukan pada rumah sakit di Kota Pekanbaru. Seluruh rumah sakit yang ada di
Kota Pekanbaru berjumlah 26 rumah sakit dengan 15 Rumah Sakit Umum (RSU) dan 9 Rumah Sakit Khusus, sesuai dengan data dari Dinas Kesehatan Kota Pekanbaru. Hasil penelitian didapatkan jumlah kasus keganasan organ tiroid sebanyak 163 kasus yang didapat berdasarkan hasil lembar jawaban pemeriksaan histopatologi dan rekam medik pada 11 rumah sakit di Kota Pekanbaru tahun 2009-2013. Penelitian ini merupakan penelitian pertama kali yang meneliti tentang keganasan organ tiroid pada rumah sakit di Kota Pekanbaru.

\section{Insiden Kasus Keganasan Organ Tiroid Tahun 2009-2013}

Berdasarkan penelitian yang dilakukan pada laboratorium diagnostik sentra patologi anatomi dan rumah sakit di Kota Pekanbaru tahun 2009-2013 pada bulan September - Desember 2015, didapatkan jumlah kasus keganasan organ tiroid sebanyak 163 kasus, dapat dilihat pada gambar 1 .

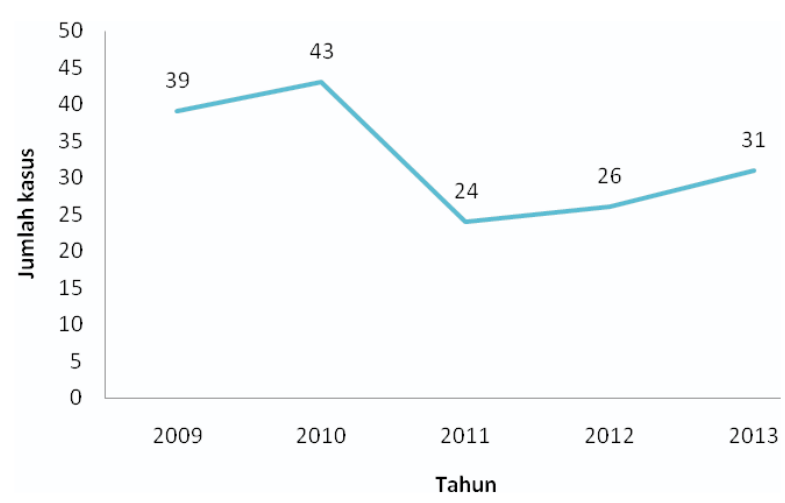

Gambar 1. Jumlah kasus keganasan organ tiroid berdasarkan tahun pada rumah sakit di Kota Pekanbaru tahun 2009-2013

Berdasarkan gambar 1, kasus keganasan organ tiroid terbanyak berada pada tahun 2010 yaitu sebanyak 43 kasus, kemudian diikuti tahun 2009 sebanyak 39 kasus. Kasus keganasan organ tiroid paling sedikit berada pada tahun 2011 yaitu sebanyak 24 kasus.

Insiden kasus keganasan organ tiroid terbanyak berada pada RSUD Arifin Achmad Provinsi Riau sebanyak 106 kasus (65\%). Setelah RSUD Arifin Achmad Provinsi Riau jumlah kasus keganasan organ tiroid terbanyak berada pada 
Rumah Sakit Awal Bros sebanyak 17 kasus $(10,4 \%)$ dan Rumah Sakit Ibnu Sina sebanyak 13 kasus (8\%). Kasus keganasan organ tiroid paling sedikit berada pada Rumah Sakit PMC, Rumah Sakit Bhayangkara, Rumah Sakit Syafira dan Rumah Sakit Nusa Lima masing-masing 1 kasus, dapat dilihat pada tabel 1.

Tabel 1. Distribusi kasus keganasan organ tiroid pada rumah sakit di Kota Pekanbaru tahun 2009-2013

\begin{tabular}{|c|c|c|c|c|c|c|c|c|c|c|c|}
\hline \multirow{2}{*}{ Rumah Sakit } & \multicolumn{2}{|c|}{2009} & \multicolumn{2}{|c|}{2010} & \multicolumn{2}{|c|}{2011} & \multicolumn{2}{|c|}{2012} & \multicolumn{2}{|c|}{2013} & \multirow{2}{*}{ Total } \\
\hline & $\mathrm{n}$ & $\%$ & $\mathrm{n}$ & $\%$ & $\mathrm{n}$ & $\%$ & $\mathrm{n}$ & $\%$ & $\mathrm{n}$ & $\%$ & \\
\hline RS. Eka Hospital & 1 & 2,6 & 0 & 0 & 2 & 8,3 & 0 & 0 & 2 & 6,5 & 5 \\
\hline RS Ibnu Sina & 6 & 15,4 & 2 & 4,7 & 1 & 4,2 & 1 & 3,8 & 3 & 9,7 & 13 \\
\hline RS. Tabrani & 3 & 7,7 & 1 & 2,3 & 0 & 0 & 0 & 0 & 0 & 0 & 4 \\
\hline RS. Lancang Kuning & 1 & 2,6 & 0 & 0 & 0 & 0 & 0 & 0 & 1 & 3,2 & 2 \\
\hline RS. Santa Maria & 3 & 7,7 & 2 & 4,7 & 1 & 4,2 & 2 & 7,7 & 4 & 12,9 & 12 \\
\hline RS. PMC & 0 & 0 & 0 & 0 & 0 & 0 & 1 & 3,8 & 0 & 0 & 1 \\
\hline RS. Awal Bros & 2 & 5,1 & 3 & 7 & 6 & 25 & 5 & 19,2 & 1 & 3,2 & 17 \\
\hline RS. Bhayangkara & 0 & 0 & 0 & 0 & 1 & 4,2 & 0 & 0 & 0 & 0 & 1 \\
\hline $\begin{array}{l}\text { RS. Syafira } \\
\text { RSUD Arifin }\end{array}$ & 0 & 0 & 0 & 0 & 1 & 4,2 & 0 & 0 & 0 & 0 & 1 \\
\hline Achmad & 23 & 59 & 34 & 79,1 & 12 & 50 & 17 & 65,4 & 20 & 64,5 & 106 \\
\hline RS. Nusa Lima & 0 & 0 & 1 & 2,3 & 0 & 0 & 0 & 0 & 0 & 0 & 1 \\
\hline Total & 39 & 100 & 43 & 100 & 24 & 100 & 26 & 100 & 31 & 100 & 163 \\
\hline
\end{tabular}

\section{Jumlah Kasus Keganasan Organ Tiroid Berdasarkan Jenis Kelamin pada Rumah Sakit di Kota Pekanbaru Tahun 2009-2013}

Jumlah kasus keganasan organ tiroid yang didapatkan dari hasil penelitian menurut jenis kelamin yaitu 136 kasus $(83,4 \%)$ pada perempuan dan 27 kasus $(16,6 \%)$ pada laki-laki. Kasus keganasan organ tiroid pada perempuan terbanyak terdapat pada tahun 2012 , yaitu $96,2 \%$, dapat dilihat pada gambar 2 .

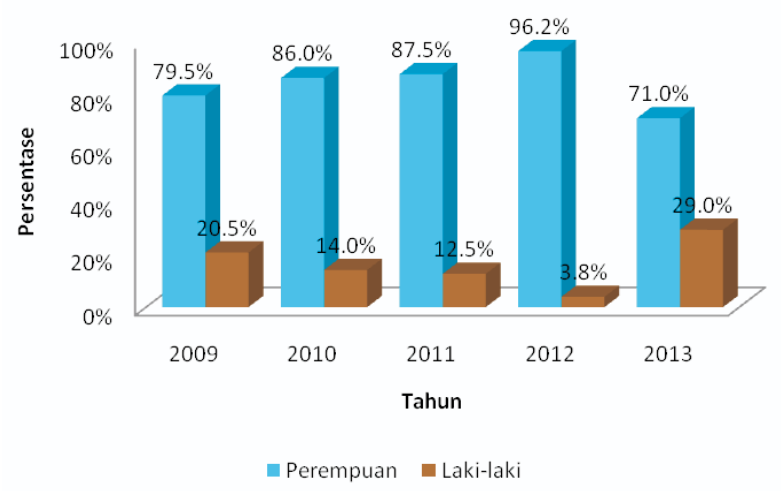

Gambar 2. Distribusi keganasan organ tiroid menurut jenis kelamin pada rumah sakit di Kota Pekanbaru tahun 2009-2013

\section{Distribusi Kasus Kegansan Organ Tiroid Berdasarkan Usia}

Usia keganasan organ tiroid dikelompokkan dalam rentang usia 10 tahun (gambar 3).

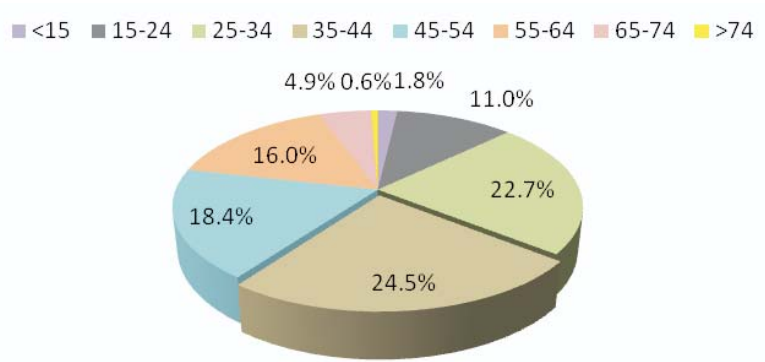

Gambar 3 Distribusi keganasan organ tiroid berdasarkan usia pada rumah sakit di Kota Pekanbaru tahun 2009-2013

Berdasarkan gambar 3 kasus terbanyak berada pada rentang usia 35-44 tahun sebanyak 40 kasus (24,5\%), kemudian diikuti rentang usia 25-34 tahun sebanyak 37 kasus $(22,7 \%)$ dan usia 45-54 tahun sebanyak 30 kasus $(18,4 \%)$. Usia diatas 74 tahun 
merupakan usia dengan jumlah kasus paling sedikit, yaitu 1 kasus $(0,6 \%)$.

\section{Distribusi Keganasan Organ Tiroid Menurut Tipe Histopatologi pada Rumah Sakit di Kota Pekanbaru Tahun 2009-2013}

Distribusi keganasan organ tiroid menurut tipe histopatologi diklasifikasikan berdasarkan WHO seperti gambar 4.

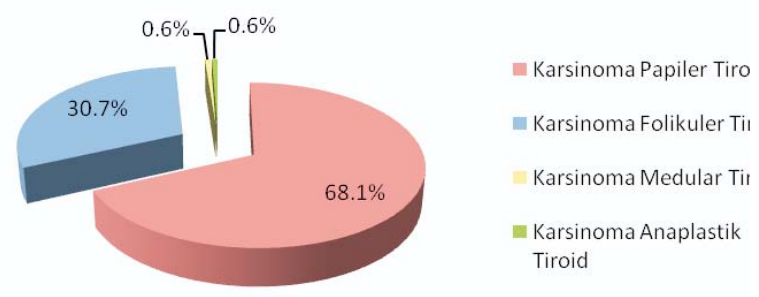

Gambar 4. Distribusi keganasan organ tiroid menurut tipe histopatologi pada rumah sakit di Kota Pekanbaru tahun 2009-2013
Gambar 4 menunjukkan distribusi keganasan organ tiroid menurut tipe histopatologi terbanyak adalah karsinoma tiroid papiler sebanyak 111 kasus $(68,1 \%)$, kemudian karsinoma tiroid folikuler sebanyak 50 kasus $(30,7)$. Kasus yang paling sedikit ialah karsinoma anaplastik dan medular tiroid yaitu masing-masingnya 1 kasus $(0,6 \%)$.

Pada tabel 2. dapat dilihat pada seluruh tipe keganasan organ tiroid lebih banyak mengenai perempuan dibandingkan laki-laki. Keganasan organ tiroid tipe medular dan anaplastik $100 \%$ terkena pada perempuan, hal ini disebabkan jumlah kasus medular dan anaplastik yang juga sangat sedikit, yaitu masing-masingnya 1 kasus.

Tabel 2. Distribusi kasus keganasan organ tiroid menurut jenis kelamin dan tipe histopatologi pada rumah sakit di Kota Pekanbaru tahun 2009-2013

\begin{tabular}{clcc}
\hline \multirow{2}{*}{ ICD-O } & \multicolumn{2}{c}{ Tenis Kelamin } \\
\cline { 3 - 4 } & & Laki-laki (\%) & Perempuan (\%) \\
\cline { 3 - 4 } $8260 / 3$ & Karsinoma Papiler Tiroid & $7(14)$ & $91(82)$ \\
$8330 / 3$ & Karsinoma Folikuler Tiroid & 0 & $43(86)$ \\
$8345 / 3$ & Karsinoma Medular Tiroid & 0 & $1(100)$ \\
$8020 / 3$ & Karsinoma Anaplastik Tiroid & $1(100)$ \\
\hline
\end{tabular}

Dilihat pada distribusi keganasan organ tiroid menurut usia dan tipe histopatologi, karsinoma papiler tiroid paling banyak terdapat pada rentang usia 25-34 tahun yaitu 28 kasus, kemudian untuk karsinoma folikuler tiroid paling banyak terdapat pada rentang usia 35-44 tahun, dapat dilihat pada tabel 3.

Tabel 3. Distribusi kasus keganasan organ tiroid menurut usia dan tipe histopatologi

\begin{tabular}{|c|c|c|c|c|c|c|c|c|c|}
\hline \multirow{2}{*}{ ICD-O } & \multirow{2}{*}{ Tipe histopatologi } & \multicolumn{8}{|c|}{ Usia } \\
\hline & & $<15$ & $\begin{array}{l}15- \\
24\end{array}$ & $\begin{array}{c}25- \\
34 \\
\end{array}$ & $\begin{array}{c}35- \\
44 \\
\end{array}$ & $\begin{array}{c}45- \\
54\end{array}$ & $\begin{array}{c}55- \\
64 \\
\end{array}$ & $\begin{array}{c}65- \\
74 \\
\end{array}$ & $>74$ \\
\hline $8260 / 3$ & Karsinoma Papiler Tiroid & 2 & 14 & 28 & 27 & 20 & 12 & 7 & 1 \\
\hline $8330 / 3$ & Karsinoma Folikuler Tiroid & 1 & 4 & 9 & 13 & 10 & 12 & 1 & 0 \\
\hline $8345 / 3$ & $\begin{array}{l}\text { Karsinoma Medular Tiroid } \\
\text { Karsinoma Anaplastik }\end{array}$ & 0 & 0 & 0 & 0 & 0 & 1 & 0 & 0 \\
\hline $8020 / 3$ & Tiroid & 0 & 0 & 0 & 0 & 0 & 1 & 0 & 0 \\
\hline
\end{tabular}




\section{PEMBAHASAN}

Jumlah kasus keganasan organ tiroid dari tahun 2009-2013 sebanyak 163 kasus yang didapat dari hasil lembar jawaban histopatologi pada 11 rumah sakit dan 4 laboratorium sentra diagnostik patologi anatomi di Kota Pekanbaru

\section{Distribusi Keganasan Organ Tiroid pada Rumah Sakit di Kota Pekanbaru Tahun 2009-2013}

Menurut hasil penelitian, kasus kanker tiroid ditemukan di 11 rumah sakit dengan jumlah penemuan kasus kanker tiroid tertinggi yaitu pada Rumah Sakit Umum Daerah (RSUD) Arifin Achmad, yaitu sebanyak 106 dari 163 kasus (65\%). RSUD Arifin Achmad sendiri merupakan rumah sakit tipe B dan merupakan pusat rujukan serta pembina Rumah Sakit Kabupaten/Kota se Provinsi Riau atau dengan kata lain, merupakan salah satu rujukan utama pasien-pasien yang berasal dari daerah. ${ }^{8}$ Jumlah penemuan kasus kanker tiroid yang kedua yaitu Rumah Sakit Awal Bros dengan 17 kasus $(10,4 \%)$ diikuti dengan Rumah Sakit Ibnu Sina dengan 13 kasus (8\%). RS Awal Bros dan RS Ibnu Sina tergolong rumah sakit swasta dengan tipe B. ${ }^{9}$

Angka penemuan kasus kanker tiroid setiap tahunnya mengalami peningkatan dan penurunan. Tahun 2009-2010 mengalami peningkatan lalu mengalami penurunan pada tahun 2011. Tahun 2012-2013 angka penemuan kasus perlahan mengalami peningkatan kembali. Penemuan kasus tertinggi terjadi pada tahun 2010 yaitu sebanyak 41 kasus. Terjadi penurunan jumlah kasus pada tahun 2011 dengan angka penemuan kasus sebanyak 21 kasus. Hasil penelitian ini berbeda dengan Putri di Sumatra Barat dimana ditemukannya peningkatan jumlah kasus hingga 3 kali lipat pada tahun 2011 dari tahun sebelumnya. ${ }^{10} \mathrm{Hal}$ ini dapat menjadi perhatian mengenai pencatatan pada tahun tersebut atau ada penyebab lain yang menyebabkan turunnya angka kejadian kanker tiroid pada tahun tersebut.

\section{Distribusi Keganasan Organ Tiroid Berdasarkan Jenis Kelamin}

Pada penelitian ini diketahui bahwa adanya dominasi pada perempuan dibandingkan laki-laki, yaitu kasus kanker tiroid pada perempuan sebanyak
136 kasus $(83,4 \%)$ dan pada laki-laki sebanyak 27 kasus $(16,6 \%)$. Hasil penelitian ini tidak jauh berbeda dengan hasil pada penelitian Utama mengenai karsinoma tiroid di RSUP Dr. Kariadi, Semarang, yaitu dari 58 kasus keganasan, ditemukan 44 kasus $(75,86 \%)$ perempuan dan 14 kasus $(24,14 \%)$ laki-laki. ${ }^{11}$ Hasil penelitian Dewi pada RSUP Sanglah Denpasar tahun 2009-2012 juga didapatkan hal yang serupa yaitu ditemukan adanya dominasi jumlah pasien berjenis kelamin perempuan dengan jumlah 152 orang $(83,5 \%)$ dari 182 pasien kanker tiroid. ${ }^{12}$ R. Sciuto et al pada penelitian kohortnya juga menyatakan hal yang sama untuk adanya dominasi pada jenis kelamin perempuan yaitu $78,6 \%$ dari 1503 kasus yang ditelitinya berjenis kelamin perempuan. ${ }^{13}$ Hasil penelitian Putri, ${ }^{10}$ Wiliyanto, ${ }^{14}$ dan Oktahermoniza, ${ }^{15}$ yang meneliti mengenai keganasan organ tiroid mendukung hasil penelitian lainnya yang menunjukkan bahwa keganasan tiroid didominasi oleh penderita berjenis kelamin perempuan, yaitu ditemukan lebih dari $80 \%$ berjenis kelamin perempuan pada masing-masing penelitian tersebut. ${ }^{10,14,15}$ Rangkuman hasil seluruh pusat patologi di Indonesia tahun 2011 menyatakan bahwa kanker secara keseluruhan didominasi oleh penderita berjenis kelamin perempuan, yaitu sebanyak 65,66\% dari keseluruhan kasus. Hasil yang sama dengan penelitian lainnya, bahwa untuk keganasan tiroid, juga didapatkan dominasi pada perempuan, yaitu sebanyak $78 \%$ dari keseluruhan kasus. $^{2}$

Menurut data RS Kanker Universitas ZhongShan, dikatakan bahwa rasio laki-laki terhadap perempuan adalah 1:2-4 kasus. Hormon pada perempuan diperkirakan berperan dalam etiologi terjadinya kanker tiroid, ${ }^{7,12,16,17}$ pada suatu penelitian menemukan pada kelenjar tiroid normal, tumor jinak dan tumor ganas tiroid terdapat reseptor estrogen dalam jumlah bervariasi. ${ }^{7,10}$ Pada jaringan karsinoma papiler tiroid kandungan reseptor estrogen (ER) dan reseptor progesteron (PR) tertinggi, disimpulkan bahwa ER dan PR merupakan faktor penting yang mempengaruhi insiden karsinoma tiroid pada perempuan. $^{7}$ 


\section{Distribusi Keganasan Organ Tiroid Berdasarkan Usia}

Kelompok usia tertinggi yang menderita kanker tiroid adalah kelompok usia 35-44 tahun diikuti kelompok usia 25-34 tahun. Kedua kelompok ini menyumbangkan kurang lebih $47 \%$ kasus setiap tahunnya. Ditemukan hasil yang sama pada rangkuman hasil seluruh pusat patologi di Indonesia tahun 2011 oleh Badan Registrasi Kanker, yaitu kelompok usia yang paling banyak menderita kanker tiroid ialah kelompok usia 35-44 tahun, lalu diikuti kelompok usia 45-54 tahun. Tidak jauh berbeda dengan penelitian Oktahermoniza, yaitu rentang usia yang paling banyak kasus keganasan organ tiroid ialah rentang usia 31-40 tahun. ${ }^{15}$

Menurut WHO, rata-rata usia untuk kanker tiroid tipe papiler adalah pertengahan usia 40 tahun hingga awal usia 50 tahun, tipe folikuler dan medular pada usia 50 tahun dan untuk tipe poorly differentiated/undifferentiated pada usia 60 tahun. ${ }^{16}$ Hasil dari penelitian Yohanes dijumpai tingginya kasus kanker tirod pada usia <60 tahun yaitu sebanyak 36 kasus dari 58 kasus, dimana pada penelitian ini hanya terdiri dari 2 kelompok usia yaitu $<60$ tahun dan e"60 tahun. ${ }^{11}$

Terdapat perbedaan penggologan usia pada masing-masing penelitian yang dilakukan. Menurut penelitian Dewi pada RSUP Sanglah Denpasar didapatkan kelompok usia yang kasusnya paling tinggi ialah kelompok usia 41-45 tahun. ${ }^{12}$ Putri mendapatkan rentang usia yang sedikit lebih muda dari penelitian lainnya yaitu 26,5\% dari seluruh sampel penelitiannya berada pada rentang usia 2130 tahun. ${ }^{10}$ Berbeda lagi dengan penelitian Wiliyanto ${ }^{14}$ dan Hundahl et al,${ }^{17}$ dimana pada kedua penelitian ini ditemukan rentang usia yang lebih tinggi dari penelitian lainnya yaitu penemuan kasus keganasan organ tiroid terbanyak pada rentang usia 40-49 tahun. $^{14}$

Putri pada penelitiannya mendapatkan adanya pergeseran rentang usia seperti pada beberapa penelitian yang dibandingkan dengan penelitian ini. Hal ini dapat disebabkan oleh karena semakin cepatnya proses karsinogensis yang terjadi diakibatkan banyak dan seringnya terpapar oleh karsinogen. ${ }^{10}$ Dewi menyatakan pada penelitiannya bahwa adanya peningkatan kasus seiring dengan pertambahan usia. Hal ini belum sepenuhnya dipahami, kemungkinan sebagian dikarenakan semakin membaiknya metode diagnostik (USG, scan tiroid, FNAC) dan peningkatan pengenalan kanker. ${ }^{12}$

\section{Distribusi Keganasan Organ Tiroid Berdasarkan Tipe Histopatologi}

Pada penelitian ini, tipe histopatologi dari kanker tiroid yang terbanyak adalah tipe papiler diikuti oleh tipe folikuler, yaitu 68,4\% karsinoma tiroid tipe papiler lalu 30,3\% karsinoma tiroid tipe folikuler. Putri pada hasil penelitiannya mendapatkan tipe keganasan yang paling banyak ditemui adalah karsinoma tiroid tipe papiler, yaitu sebanyak $73,5 \%$ diikuti karsinoma tiroid tipe folikuler sebanyak 21,6\% dari keseluruhan kasusnya. ${ }^{10}$ Hasil yang tidak jauh berbeda juga didapatkan pada penelitan Dewi, ${ }^{12}$ Wiliyanto,${ }^{14}$ dan penelitian kohort R.Sciuto et al, ${ }^{13}$ yaitu ditemukan tipe yang paling sering ditemui dari keganasan tiroid ialah karsinoma tiroid tipe papiler, yaitu lebih dari 70\%. ${ }^{12-14}$ Menurut jurnal kanker oleh The American Cancer Society, dikatakan bahwa $80 \%$ dari keseluruhan kasus kanker tiroid merupakan tipe papiler dan 10-20\% merupakan tipe folikuler. ${ }^{18}$ Tipe papiler juga merupakan tipe tersering, yaitu $75 \%$ diikuti oleh tipe folikuler yaitu $10 \%$ pada epidemiologi dan gambaran klinis kanker tiroid oleh Universitas Sumatra Utara divisi onkologi. ${ }^{16}$ Hundahl et al mengumpulkan 53.856 kasus karsinoma tiroid selama 10 tahun, yaitu 1985-1995 di Amerika Serikat, diantaranya ditemukan tipe papiler sebanyak 79,3\%. ${ }^{17}$ Data dari RS Kanker Universitas Zhongshan selama 1985-1997 menunjukkan tipe papiler menduduki $74,3 \%$ dari keseluruhan kanker tiroid. ${ }^{7}$

Seperti yang dikatakan pada teori bahwa salah satu faktor yang mempengaruhi gambaran histopatologi karsinoma tiroid adalah jumlah asupan yodium. Putri mengatakan, rendahnya kadar yodium pada suatu daerah berasosiasi pada peningkatan jumlah kegansatan tiroid tipe folikuler dan anaplastik, namun menurunkan tipe papiler. Diketahui bahwa peran dari yodium dalam karsinogenesis tiroid adalah memodulasi morfologi tumor dari pada menginisiasi kanker. ${ }^{10}$

Hasil yang sedikit berbeda ditemukan pada penelitian Oktahermoniza, yaitu ditemukan angka penemuan kasus yang tidak jauh berbeda antara 
karsinoma tiroid tipe papiler dengan karsinoma tiroid tipe folikuler, yaitu $52,1 \%$ dengan $41,8 \%$ dari keseluruhan kasus, namun tetap seperti penelitian lainnya ditemukan tipe yang paling banyak adalah karsinoma tiroid tipe papiler. ${ }^{15}$ Didapatkan hasil yang berbeda pada suatu penelitian yang sudah lama dilakukan, dimana penelitian ini dipublikasikan pada tahun 1975 oleh Heitz et al. Hasil penelitian ini, ditemukan tipe yang paling banyak dijumpai adalah karsinoma tiroid tipe folikuler, yaitu 39,3\% dari keseluruhan kasus, diikuti oleh tipe papiler sebanyak 25,3\% dan anaplastik 25,7\%. Medular menempati tempat terakhir dengan jumlah kasus terendah yaitu $1,7 \%$. Angka tertinggi tipe folikuler adalah pada tahun 1944-1953 yaitu mencapai 51,9\% lalu menurun menjadi 38,1\% pada tahun 1964-1973. Tipe yang jumlahnya stabil selama periode penelitian 30 tahun ialah tipe anaplastik. ${ }^{19}$ Belum ada keterangan pasti mengenai perbedaan hasil penelitian tersebut. Perbedaan ini dapat disebabkan oleh berbedanya pola asupan yodium pada tahun penelitian yang dilakukan oleh Heitz dengan tahun penelitian-penelitian lainnya.

Walaupun kanker tiroid tipe papiler ini menduduki jumlah tertinggi untuk kanker tiroid, tipe papiler diketahui memiliki prognosis yang baik, yaitu lebih dari $90 \%$ untuk pasien yang usianya kurang dari 45 tahun. ${ }^{16}$ Hasil analisa statistik oleh Oktahermoniza mengatakan bahwa tipe histopatologi berhubungan secara bermaksa dengan survival. Ketahanan hidup 5 tahun terbaik terdapat pada tipe papiler yaitu $98,4 \%$ sedangkan tipe folikuler dan medular masing-masing 95,9\% dan $50 \%$. Ketahanan hidup untuk tipe anaplastik pada penelitian ini dinyatakan hanya 3 bulan. ${ }^{15}$

Penelitian ini membandingkan distribusi berdasarkan jenis kelamin dan usia dengan tipe histopatologi dan mendapatkan hasil yaitu untuk untuk semua tipe keganasan organ tiroid penemuan kasus paling banyak yaitu berjenis kelamin perempuan. Pada karsinoma medular dan anaplastik, dikarenakan angka penemuan kasusnya yang rendah, didapatkan $100 \%$ berjenis kelamin perempuan. Menurut WHO, tipe papiler rawan terjadi dibawah usia 15 tahun, sering terjadi pada usia 20-50 tahun dengan rasio perempuan:laki-laki 4:1, dan tidak jelas dominasi perempuan dibandingkan laki-lakinya pada usia diatas 50 tahun. Untuk tipe medular dinyatakan usia rata-rata perempuan yang terkena karsinoma tiroid berusia 50 tahun, hal ini terkait adanya peningkatan fungsi dari mutasi germline pada RET proto-oncogene [multiple endocrine neoplasia (MEN) type $2 A$ and $2 B$ familial MTC (FMTC)] dengan autosomal dominan turunan. Tipe anaplastik juga lebih sering mengenai jenis kelamin perempuan dengan rasio 1,5:1. ${ }^{17}$ Pernyataan WHO tersebut seiring dengan hasil pada penelitian ini yaitu ditemukan masingmasing 1 kasus karsinoma tiroid tipe anaplastik dan medular, dimana kedua penderita tersebut berjenis kelamin perempuan, dengan usia 55 tahun dan 57 tahun.

Seperti yang telah dikatakan sebelumnya bahwa jumlah kasus keganasan tiroid meningkat seiring dengan pertambahan usia. Pada usia lanjut, laki-laki memiliki risiko yang lebih tinggi terkena kanker tiroid dan kanker tiroid tersebut lebih agresif jika dibandingkan kanker tiroid pada perempuan. Dinyatakan juga bahwa angka kematian dari penderita karsinoma papiler tiroid biasanya lebih tinggi pada orang tua. Hal ini diperkirakan merupakan konsekuensi dari peningkatan aktivitas mitosis dari tumor dan hal tersebut meningkatkan kemungkinan adanya metastasis. Peningkatan ini dipengaruhi oleh ekspresi gen NDRG2 serta gen BRAF yang bermutasi. Karsinoma folikuler tiroid prognosisnya lebih buruk dibandingkan papiler dikarenakan lebih memungkinkan untuk metastasis hematogen jauh. Begitu juga dengan tipe anaplastik dan medular, dimana prevalensi jauh lebih tinggi pada usia dewasa hingga tua dibandingkan usia muda. Dapat dinyatakan bahwa usia menjadi salah satu penilaian dari baik atau buruknya prognosis keganasan tiroid. ${ }^{20}$

\section{KESIMPULAN}

Distribusi keganasan organ tiroid menurut jenis kelamin terbanyak yaitu perempuan $(83,4 \%)$, dengan rentang usia 35-44 tahun (24,5\%). Tipe histopatologis paling banyak adalah karsinoma tiroid tipe papiler $(68,1 \%)$.

\section{DAFTAR PUSTAKA}

1. World Health Organization. Cancer mortality dan morbidity. United state : Global Health 
Observatory ; 2014 [cited : 2014 July 24]. Available from:http://www.who.int/gho/ncd/ mortality_morbidity/cancer/en/

2. Yayasan Kanker Indonesia. Kanker di Indonesia tahun 2011 data histopatologi. Jakarta;2015

3. Manuaba TW. Panduan penatalaksanaan kanker solid PERABOI 2010. Jakarta:Sagung Seto;2010:53-71

4. National Cancer Institute. Thyroid cancer 2011. United States : National Institute of Health; 2014 [cited : 2014 July 24]. Available from: http:// seer.cancer.gov/statfacts/html/thyro.html

5. Departemen Kesehatan Republik Indonesia. Situasi penyakit kanker. Pusat Data dan Informasi Departemen Kesehatan RI; 2015. Available from: http://www.depkes.go.id/ download.php?file=download/pusdatin/ infodatin/infodatin-kanker.pdf

6. Kumar V, Cotran RS, Robbins SL. Buku ajar patologi robbins.7(2). Jakarta:EGC;2012:82024.

7. Desen W. Buku ajar onkologi klinik. Edisi 2. Jakarta : Badan Penerbit FKUI ; 2008: 27-297.

8. RSUD Arifin Achmad Provinsi Riau. RSUD arifin achmad provinsi riau.;2015 [diakses : 20 Oktober 2015]. Dapat diakses pada : http:// www.rsudpekanbaru.com/?page_id=4

9. Kementrian Kesehatan Republik Indonesia. Data rumah sakit online;2015 [diakses :23 Oktober 2015]. Dapat diakses pada : http:// sirs.buk.depkes.go.id/rsonline/ Peta_list.php?ctlsearch For $=$ $\mathrm{p}$ e $\mathrm{k}$ a n b a r u s i m p le $\mathrm{S} \mathrm{r} \mathrm{ch}$ Fields ComboOpt $=$ KA B \% 2 F KOTA

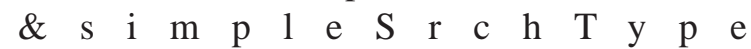
ComboNot $=\&$ simpleSrchTypeComboOpt $=$ Contains\&a $=$ integrated\&id $=1 \&$ criteria $=$ and

10.Putri E, Khambri D, R Renita S. Hubungan daerah tempat tinggal dengan gambaran histopatologi karsinoma tiroid pada masyarakat sumatera barat. Jurnal Kesehatan Andalas;2014:3(2)
11.Utama Y D. Nilai diagnostik karakteristik klinis dibandingkan dengan biopsi patologi anatomi dalam mendiagnosis karsinoma tiroid. Universitas Diponegoro;2015

12.Dewi I G, Adiputra P A. Karakteristik penderita kanker tiroid di bagian bedah onkologi RSUP Sanglah Denpasar tahun 2009-2012. E-Jurnal Medika Udayana;2015:4(3)

13. Sciuto R, et al. Natural history and clinical outcome of differentiated thyroid carcinoma: a retrospective analysis of 1503 patients treated at a single institution. Annals of Oncology 20. 2009

14. Wiliyanto O. Insiden kanker kepala leher berdasarkan diagnosis patologi anatomi dir s dr. Kariadi Semarang periode 1 januari 2001-31 desember 2005. Fakulats Kedokteran Universitas Diponegoro;2006

15.Oktahermoniza et al. Analisis ketahanan hidup lima tahun kanker tiroid yang dikelola di RSUP dr. M. Djamil Padang. Jurnal Kesehatan Andalas;2013: 2(3)

16.DeLellis R A et al. Pathology and genetics of tumours of endocrine organs. IARC Press;2004:50-91

17.Hundahl SA, Cady B, Cunningham MP et al. Initial result from prospective cohort study of 5583 cases of thyroid carcinoma treated in the united states during 1996. U.S and German Thyroid Cancer Study Group. An American College of Surgeons Commission on Cancer Patient Care Evaluation study. Cancer;2000

18. Schneider DF, Chen H. New development in the diagnosis and treatment of thyroid cancer. CA Cancer J Clin;2013:63(6)

19. Heitz P, Moser H, \& Staub J J. Thyroid cancer a study og 573 thyroid tumors and 161 autopsy cases obser ved over a thirty-year period. Cancer ; 1976:37(5)

20.Gesing A, Lewiñski, A \& Karbownik-Lewiñska $\mathrm{M}$. The thyroid gland and the process of aging; what is new. Thyroid Res;2012:5(1) 